\title{
Ultrastructural Studies on Fibrillar Papillae Formed in Welsh Onion Mesophyll Cells Infected by Puccinia allii
}

\author{
Katsumi Akutsu*, Yoshiko Daigo* and Satoshi Okuyama*
}

\begin{abstract}
Papillae containing ultrastructurally different components were observed in mesophyll cells of Welsh onion leaves inoculated with Puccinia allii. The components of the papillae observed in the mesophyll cells before penetration by the fungus were different from those formed after penetration. The papillae found before the fungal penetration were constituted only with fibrillar components, while the papillae formed after penetration contained nonfibrillar components in addition to the fibrillar components. The non-fibrillar components were primarily found around the haustorial necks, and sometimes around the haustorial bodies. Ultrastructural analysis of mesophyll cells of the leaves (cv. Ishikura-ippon-futonegi) before the papilla formation elucidated that the plasmalemma in mesophyll cells adjacent to the haustorial mother cells was retracted from the cell walls, and tubular or vesicular structures were observed in the paramural spaces. These structures appeared to be continuous with the plasmalemma or endoplasmic reticulum in the host cytoplasm. In addition to these structures, fibrillar materials were observed in the paramural spaces. The tubular or vesicular structures may play roles in the formation of the fibrillar papillae in Welsh onion-P. allii system.
\end{abstract}

(Received March 14, 1985)

Key Words : ultrastructure, Puccinia allii, Welsh onion, papilla.

\section{Introduction}

Formation of wall appositions, commonly referred to as papillae, has been well known as a response of host cells to fungal penetration. The formation and role of papillae have been reviewed recently ${ }^{4,13)}$. The papillae are always in contact with the host cell walls but may, or may not, resemble it in appearance. The papillae are classified roughly into non-fibrillar type and fibrillar type according to ultrastructural appearance. Most papillae are non-fibrillar type, and range from being primarily electron-lucent to those which are more or less electron-opaque. The non-fibrillar papillae have been well studied by many researchers, and many lines of histochemical, ultrastructural and phytopathological evidence have been accumulated to suggest the formation mechanism and their roles ${ }^{2-5,13,16-18,20)}$. Although there are some reports on fibrillar papillae $e^{1,2,10,11,13}$, 14), available information is not enough to speculate the mechanism of their formation and their roles in primary interactions.

In Welsh onion-Puccinia allii system which have been known to form the fibrillar papillae ${ }^{2,14)}$, we have studied ultrastructurally the formation process and possible components of the papillae. This paper presents ultrastructural evidence which suggest the

\footnotetext{
* Faculty of Agriculture, Ibaraki University, Ami-machi, Ibaraki 300-03, Japan 茨城大学農学部
} 
mechanism of formation and their roles in the Welsh onion-P. allii interactions.

\section{Materials and Methods}

The Welsh onion (Allium fistulosum L.) cultivars used in this study were Nagayoshifuyu-ippon-futonegi, Ishikura-ippon-futonegi, Shōnan-negi and Kujō-hosonegi. The seeds were sown in sterile soil in pots, and Kujo-hosonegi and other cultivars were grown for 5 weeks and 15 weeks, respectively, in a greenhouse. The leaf blades were cut into disks of $8 \times 80 \mathrm{~mm}$ in size, and of $8 \mathrm{~mm}$ diameter, respectively. These disks were placed on moist filter paper in sterile Petri dishes.

Urediniospores of Welsh onion rust (Puccinia allii (de Candolle) Rudolphi) were first obtained from field-infected Welsh onion plants. A single-pustule isolate was used for all subsequent experiments. The spores were produced in bulk on the cultivar Kujohosonegi and stored at $-50 \mathrm{C}$. Before use, the spores were treated by the method described by Heath ${ }^{12}$ to remove self-inhibitors of germination. The spore suspension was adjusted to $1 \times 10^{5}$ spores $/ \mathrm{ml}$ in distilled water.

The leaf disks $(8 \times 80 \mathrm{~mm}$ in size) were inoculated by spraying with $10 \mathrm{ml}$ of the urediniospore suspension per leaf disk. For light and electron microscopy, the ringed leaf disks ( $8 \mathrm{~mm}$ diameter) were inoculated with $5 \mu$ l droplet of the suspension per leaf disk. After inoculation, the leaf disks were kept in dishes at $100 \%$ relative humidity for $24 \mathrm{hr}$ at $20 \pm 2 \mathrm{C}$ in the dark, and further incubated at $20 \pm 2 \mathrm{C}$ under $12 \mathrm{hr}$ illumination of fluorescent light per day.

For light microscopy, the inoculated leaf disks were fixed with FAA solution 6, 12, 18, 24, 48 and $72 \mathrm{hr}$ after inoculation, stained with methyl blue solution, and then examined with a light microscopy.

Rectangular segments of the inoculated leaf disks were taken at 24,48 and $72 \mathrm{hr}$ after inoculation for electron microscopy. The leaf segments were fixed for $2 \mathrm{hr}$ in $3 \%$ glutaraldehyde in $0.1 \mathrm{M}$ phosphate buffer ( $\mathrm{pH} 7.0$ ) containing $0.2 \mathrm{M}$ sucrose. After rinsing in the same buffer overnight, they were post-fixed in $1 \%$ osmium tetroxide in Sörensen phosphate buffer at $0 . \mathrm{C}$ for $2 \mathrm{hr}$, and then rinsed for $10 \mathrm{~min}$ in $0.1 \mathrm{M}$ phosphate buffer three times. After dehydration in a graded series of ethanol, the fixed tissues were embedded in Quetol 812. Thin sections were post-stained in uranyl acetate for $20 \mathrm{~min}$ followed by lead citrate for $5 \mathrm{~min}$ and observed with an electron microscope (JEM 100-S).

\section{Results}

\section{Infection types of Welsh onion cultivars inoculated with Puccinia allii}

Infection types of four Welsh onion cultivars inoculated with $P$. allii were expressed according to the method described for oat-Puccinia coronata Corda f. sp. avenae system ${ }^{6}$. Shōnan-negi and Kujō-hosonegi were highly susceptible to the fungus. Nagayoshi-fuyuippon-futonegi and Ishikura-ippon-futonegi showed varied degrees of responses from intermediate susceptibility to intermediate resistance (Table 1). 
Table 1. Infection types of four Welsh onion cultivars inoculated by urediniospores of Puccinia allii

\begin{tabular}{l|c}
\hline \multicolumn{1}{c|}{ Cultivars } & Infection types $^{\text {a) }}$ \\
\hline Nagayoshi-fuyu-ippon-futonegi & $2-3$ \\
Ishikura-ippon-futonegi & $2-3$ \\
Shōnan-negi & 4 \\
Kujō-hosonegi & 4 \\
\hline
\end{tabular}

a) Infection types were examined 2 weeks after inoculation, and expressed in accordance with the description in oat-Puccinia coronata f. sp. avenae ${ }^{6}$.

\section{Light microscopy of infection process of $P$. allii on Welsh onion leaves}

Germination and appressorium formation of urediniospores over stomata were similar on the four cultivars tested. Invasion through stomata occurred between 6 and $12 \mathrm{hr}$ after inoculation. Formation of haustoria in mesophyll cells was observed between 12 and $24 \mathrm{hr}$ after inoculation. Papillae were usually observed in mesophyll cells of the four cultivars at the sites the fungus attempted penetration regardless of success or failure of haustorium formation by the fungus.

\section{Electron microscopy of papillae in mesophyll cells of Welsh onion leaves inoc-} ulated by $P$. allii

Specimens of electron microscopy were taken from leaf disks of the four cultivars 24 , 48 and $72 \mathrm{hr}$ after inoculation. Two types of papillae, different in ultrastructural appearance, were observed in all cultivars. One of the papillae was constituted with fibrillar components (Plate I-1), and was mainly observed in cells which had not been penetrated by infection pegs (Table 2). The another papillae were constituted with both fibrillar and non-fibrillar components (Plate I-2), and found in the mesophyll cells in which haustoria had already been formed (Table 2).

Table 2. Papillae formed in leaf mesophyll cells of Welsh onion cultivars inoculated by Puccinia allii ${ }^{\text {a) }}$

\begin{tabular}{l|c|c|c|c}
\hline \multirow{2}{*}{ Cultivars } & \multicolumn{2}{|c|}{ Numbers of papillae } & \multicolumn{2}{c}{ None $^{\text {c) }}$} \\
\cline { 2 - 4 } & Type I & Type II & Type III & \\
\hline Nagayoshi-fuyu-ippon-futonegi & $13(0)^{\mathrm{d})}$ & 0 & $15(15)^{\mathrm{d})}$ & 2 \\
Ishikura-ippon-futonegi & $18(0)$ & 0 & $23(21)$ & 5 \\
Shönan-negi & $7(0)$ & 0 & $18(17)$ & 4 \\
Kujō-hosonegi & $8(0)$ & 0 & $21(21)$ & 8 \\
\hline
\end{tabular}

a) The mesophyll cells 48 and $72 \mathrm{hr}$ after inoculation were examined with an electron microscope.

b) Type I, papillae with fibrillar components only; Type II, papillae with non-fibrillar components only; Type III, papillae with both fibrillar and non-fibrillar components.

c) Numbers of haustoria formed without papillae in the mesophyll cells.

d) Numbers of haustoria formed beneath papillae in the mesophyll cells.

Process of the haustorial formation by $P$. allii were divided into six stages in the mesophyll cells of Ishikura-ippon-futonegi (Fig. 1). The examination of components of 
the papillae at each stage showed that papillae in stages from 1 to 4 were constituted with fibrillar components (Table 3). In the papillae at stages 5 and 6 , the non-fibrillar components were observed around the haustorial necks in addition to the fibrillar components (Plate I-2, arrow and Table 3).

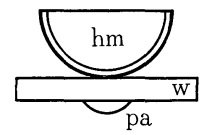

stage 1

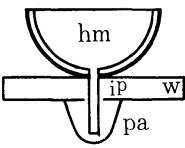

stage 4

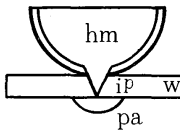

stage 2

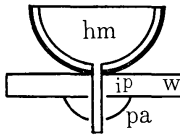

stage 5

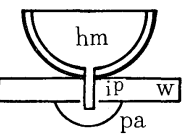

stage 3

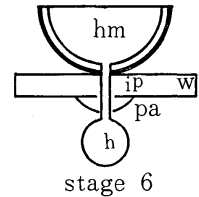

Fig. 1. Diagrams illustrating process of haustorial formation by Puccinia allii in mesophyll cells of Welsh onion leaves. h, haustorium; hm, haustorial mother cell; ip, infection peg; pa, papilla; w, cell wall.

Table 3. Changes of papilla components during the process of haustorial formation by Puccinia allii in mesophyll cells of Welsh onion leaves ${ }^{\text {a) }}$

\begin{tabular}{c|c|c|c}
\hline \hline \multirow{2}{*}{ Process of haustorial formation } & \multicolumn{3}{|c}{ Numbers of papillae } \\
\cline { 2 - 4 } & Type I & Type II & Type III \\
\hline Stage 1 & $5(17)^{\mathrm{d})}$ & 0 & 0 \\
Stage 2 & $11(14)$ & 0 & 0 \\
Stage 3 & $7(8)$ & 0 & 0 \\
Stage 4 & $6(6)$ & 0 & 0 \\
Stage 5 & $1(15)$ & 0 & 10 \\
Stage 6 & $0(21)$ & 0 & 18
\end{tabular}

a) The mesophyll cells (cv. Ishikura-ippon-futonegi) 24 and $48 \mathrm{hr}$ after inoculation were examined with an electron microscope.

b) The process of haustorial formation was divided into six stages as shown in Fig. 1.

c) Type I, papillae with fibrillar components only; Type II, papillae with non-fibrillar components only; Type III, papillae with both fibrillar and non-fibrillar components.

d) Total numbers of the mesophyll cells observed at each stage of the haustorial formation.

\section{Ultrastructural changes in the mesophyll cells of Welsh onion leaves inoculated by $P$. allii}

The changes in the mesophyll cells before papillae formation (Fig. 1, stage 1) were examined in the cultivar Ishikura-ippon-futonegi inoculated by the fungus. The mesophyll cells adjacent to infection hyphae differed little, if any, from those in uninoculated leaves (Plate I -3). In the mesophyll cells adjacent to the haustorial mother cells, convolution of plasmalemma, electron-density of cytoplasmic matrix and accumulation of 
organelle became more prominent (P1ate $\mathrm{I}-4$ and $I-5$, and Table 4 ). The plasmalemma was frequently retracted from the cell walls in such mesophyll cells, and tubular or vesicular structures were present within the paramural spaces (Plate II -5 7, and Table 4). These structures appeared to be continuous with the plasmalemma (Plate $\mathbb{I}-5$, arrow and Plate $I-7$, arrow 1), or endoplasmic reticulum (Plate $I-6$, arrows). In addition to these structures, fibrillar materials were also observed in the paramural spaces (Plate II-7 and Table 4). The fibrillar materials appeared to be continuous with the tubular or vesicular structures (Plate $\Pi-7$, arrows 2).

The tubular or vesicular structures were observed in the paramural spaces during the papilla formation, and appeared to be continuous with the fibrillar materials around the papillae (Plate $\Pi-8,9$ arrows).

Table 4. Ultrastructural changes before formation of papillae in mesophyll cells of Welsh onion leaves inoculated by Puccinia allii ${ }^{\text {a }}$

\begin{tabular}{|c|c|c|}
\hline \multirow{2}{*}{ Ultrastructural changes } & \multicolumn{2}{|c|}{ Numbers of mesophyll cells } \\
\hline & Inoculated leaves $\left.{ }^{b}\right)$ & Uninoculated leaves ${ }^{c}$ ) \\
\hline Paramural spaces $^{\mathrm{d})}$ & 10 & 3 \\
\hline Aggregation of cytoplasm & 7 & 0 \\
\hline Tubular or vesicular structures ${ }^{\mathbf{e}}$ & 9 & 1 \\
\hline Fibrillar materials ${ }^{\mathrm{e}}$ & 7 & 2 \\
\hline
\end{tabular}

a) Ultrastructural changes in the mesophyll cells were examined in mesophyll cells at stage 1 used in Table 3.

b) Twelve mesophyll cells adjacent to haustorial mother cells were examined.

c) Twenty mesophyll cells were examined.

d) Areas formed with convolution of palsmalemma.

e) Observed in the paramural spaces.

\section{Discussion}

The present study with electron microscopy elucidated different types of papillae in mesophyll cells of Welsh onion leaves inoculated by Puccinia allii. The ultrastructural features of papillae formed in mesophyll cells before penetration by the fungus were different from those formed after penetration. The papillae found before penetration were constituted with fibrillar components, while those observed after penetration contained non-fibrillar components in addition to the fibrillar components. After formation of haustorial mother cells by the fungus, the fibrillar components were found in paramural spaces of the mesophyll cells, which had been often formed under the haustorial mother cells, but the non-fibrillar components were not found. The non-fibrillar components were present around haustorial necks, and sometimes observed around the haustorial bodies. These facts suggest that the fibrillar components may appear as a host resistant response to the fungal penetration, while the non-fibrillar components may be the products of initial interactions between the haustoria and the host cytoplasm rather than the constituents of barries to the fungal penetration. These specu- 
lations are supported by facts that well-developed papillae which surrounded infection pegs occurring necrosis were constituted with the fibrillar components only ${ }^{2}$, and that the non-fibrillar components were similar to components of encapsulation surrounding the haustoria.

In Welsh onion-P. allii system, Kajiwara named these fibrillar and non-fibrillar components fibrillar sheath and sheath, respectively ${ }^{15}$, and pointed out that the fibrillar sheath and the sheath may probably correspond to papillae and initiators of encapsulation, respectively. The present study showed that ultrastructurally different fibrillar and non-fibrillar components are formed at different stages of infection, suggesting that their functions may be different. We propose to call these fibrillar and non-fibrillar components as fibrillar papillae and sheath, respectively.

Before the formation of papillae, the tubular or vesicular structures were observed in the paramural spaces of the mesophyll cells contacted by the haustorial mother cells. These structures seemed to originate from invaginated host plasmalemma or endoplasmic reticulum. Such structures have been often observed in host cytoplasm around non-fibrillar papillae, and have been assumed to take part in the formation of their papillae ${ }^{2,3,7-9,18-20)}$. In the case of the fibrillar papillae, such tubular or vesicular structures had not been observed, hence led to a speculation that the fibrillar papillae might not be formed in the same manner as the non-fibrillar papillae ${ }^{18)}$. Our electron microscopic study, however, suggested that the tubular or vesicular structures might play roles in the formation of the papillae as well as the non-fibrillar papillae.

\section{Literature cited}

1. Abu-Zinada, A. A. H., Cobb, A. and Boulter, D. (1975). Physiol. Pl. Pathol. 5 : 113-118.

2. Akutsu, K., Amano, K., Doi, Y. and Yora, K. (1977). Ann. Phytopath. Soc. Japan 43: 491-496.

3. Akutsu, K., Doi, Y. and Yora, K. (1980). Ibid. 46:667-671.

4. Aist, J. R. (1976). Ann. Rev. Phytopath. $14: 145-163$.

5. Aist, J. R., Waterman, M. A. and Israel, H. W. (1979). In Recognition and Specificity in Plant Host-Parasite Interactions (Daly, J. M. and Uritani, I. eds.). Japan Sci. Soc. Press, Tokyo and Univ. Park Press, Boltimore. pp. 85-97.

6. Ando, K., Ono, Y., Kakishima, M., Katsuya, K., Sato, S. and Sato, T. (1983). Methods in Plant Pathology (Sato, S. et al. eds.). Kōdan-sha, Japan. pp. 43-45 (in Japanese).

7. Bishop, C. D. and Cooper, R. M. (1983). Physiol. Pl. Pathol. 22 : 15-27.

8. Cooper, R. M. (1981). In Plant Disease Control: Resistant and Susceptibility (Staples, R. C. and Toenniesen, G. H. eds.). John Wiley and Sons, New York. pp. 105-142.

9. Hanchey, P. and Wheeler, H. (1971). Phytopathology $61: 33-39$.

10. Harder, D. E. (1978). Can. J. Bot. $56: 214-224$.

11. Hardwick, N. V., Greenwood, A. D. and Wood, R. K. S. (1971). Ibid. $49: 383-390$.

12. Heath, M. C. (1971). Phytopathology $61: 383-388$.

13. Heath, M. C. (1980). Ann. Rev. Phytopath. $18: 211-236$.

14. Kajiwara, T. (1971). In Morphological and Biochemical Events in Plant-Parasite Interaction (Akai, S. and Ouchi, S. eds.). Mochizuki Publishing Co., Japan. pp. 255-277.

15. Kajiwara, T. (1972). Shokubutsu Bōeki $26: 421-426$ (in Japanese).

16. Kunoh, H. and Ishizaki, H. (1976). Ann. Phytopath. Soc. Japan 42:30-34.

17. Kunoh, H. and Ishizaki, H. (1976). Physiol. P1. Pathol. 8: 91-96.

18. Littlefield, L. J. and Heath, M. C. (1979). In Ultrastructure of Rust Fungi : Vegetative Growth in the Susceptible Host. Academic Press, New York, San Francisco, London. pp. 165-193.

19. Politis, D. J. and Goodman, R. N. (1978). Phytopathology $68: 309-316$.

20. Zeyen, R. J. and Bushnell, W. R. (1979). Can. J. Bot. $57: 898-913$. 


\section{和 文 摘 要}

阿久津克己・大胡佳子・奥山 哲 : ネギさび病菌感染葉葉肉細胞にみられる繊維性パピラの電顕観察

ネギさび病菌 (Puccinia allii) を接種した 4 品種のネギ葉部葉肉細胞で, 微細構造的に異なる成分を含むパ ピラが観察された。パピラ成分はさび病菌の葉肉細胞への侵入前後で異なった。侵入前もしくは侵入時のパピ ラでは繊維性成分だけが観察されたが，侵入後のパピラでは䋊維性成分の外に非䋊維性成分が観察された。非 繊維性成分は吸器頸部の周囲でよく見られ, 時々吸器本体部周辺でも観察され, その出現は吸器形成之密接な 関係があると推察された。パピラ形成以前の侵入に対する葉肉細胞内の反応を電顕レベルで調べた。吸器母細 胞と接した葉肉細胞で, 細胞膜の陷入, 細胞質の凝集がしばしば認められた。細胞膜の陷入で発達した paramural space (細胞壁・細胞膜間隙) で, 細胞膜あるいは小胞体と連絡した管状むしくは小胞状の器官が集積 し，その付近こは纎維性物質が観察された。パピラ周辺の緎維性物質と隣接した小胞状器官も観察され，パピ ラ形成にこれらの器官が関与することが示唆された。

\section{Explanation of plates}

\section{Plale I}

Electron micrographs of mesophyll cells of Welsh onion leaf blades (cv. Ishikura-ippon-futonegi) inoculated by Puccinia allii.

1. A papilla containing fibrillar components in the mesophyll cell contacted by the haustorial mother cell.

2. A papilla containing both fibrillar and non-fibrillar components in the mesophyll cell at the stage of haustorium formation. Note the non-fibrillar components around the haustorial neck (arrow).

3. The mesophyll cell adjacent to the infection hypha.

4. The mesophyll cell adjacent to the haustorial mother cell.

\section{Plate II}

5. An area of convoluted plasmalemma in the mesophyll cell adjacent to the haustorial mother cell. Note tubular structures continuous with the plasmalemma in the paramural space (arrow).

6. Accumulation of the tubular structures in the paramural space of the mesophyll cell adjacent to the haustorial mother cell. Note some tubular structures continuous with endoplasmic reticulum (arrows).

7. Fibrillar materials in the paramural space of the mesophyll cell adjacent to the haustorial mother cell. Note the tubular or vesicular structures continuous with the plasmalemma (arrow 1) or the fibrillar materials (arrows 2).

8. and 9. Deposition of the fibrillar materials in the paramural spaces of the mesophyll cells adjacent to the haustorial mother cells. Note the vesicular structures continuous to the fibrillar materials around the papillae (arrows). All scales: $500 \mathrm{~nm}$.

Abbreviation: c, chloroplast; er, endoplasmic reticulum; fm, fibrillar materials; h, haustorium; hm, haustorial mother cell; ih, infection hypha; ip, infection peg; is, intercellular space; 1, lipid body; $\mathrm{m}$, mitochondrion; p, plasmalemma; pa, papilla; ps, paramural space; ts, tubular structure; vs, vesicular structure; w, cell wall. 


\section{Plate I}

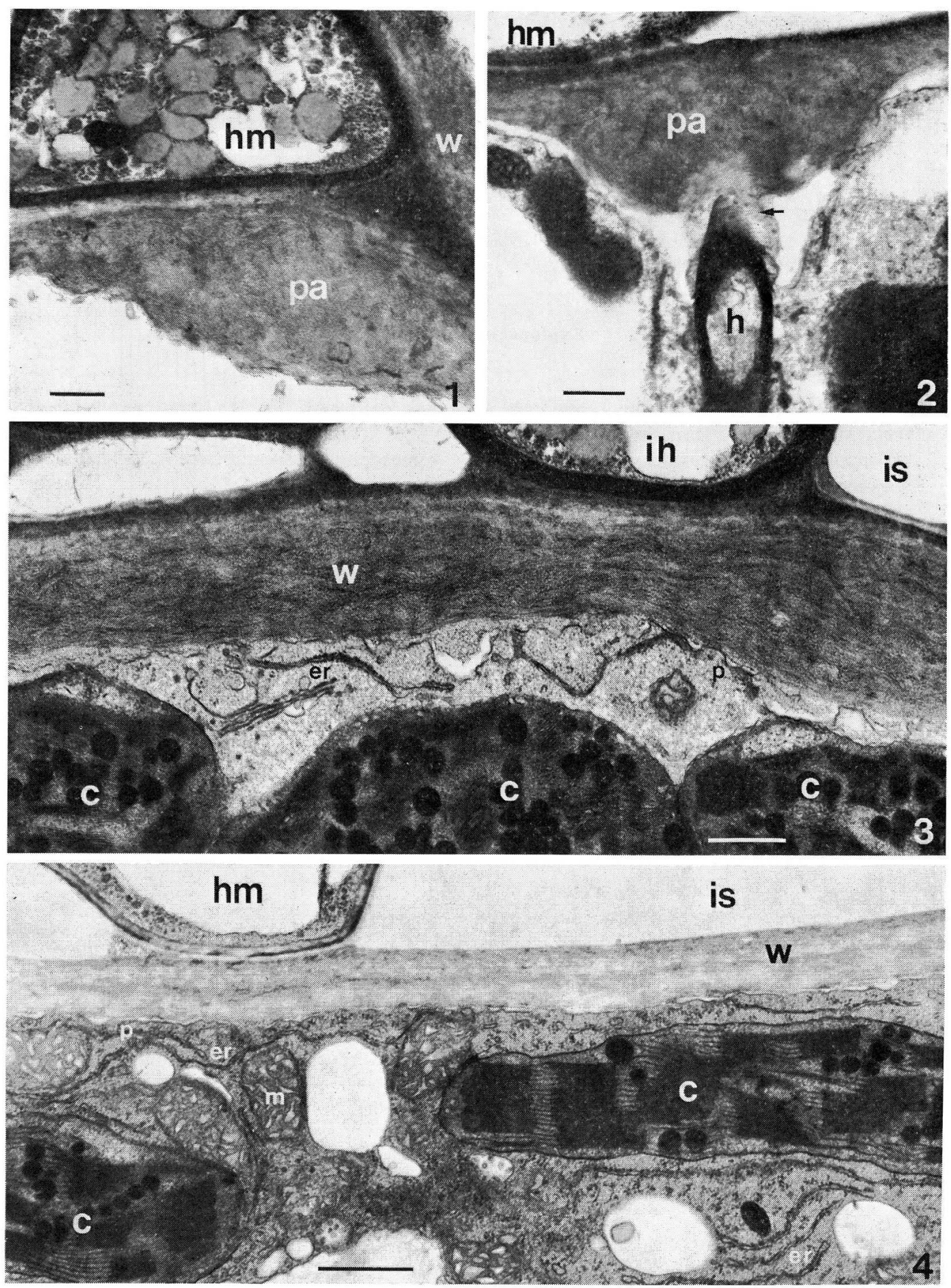


Plate II
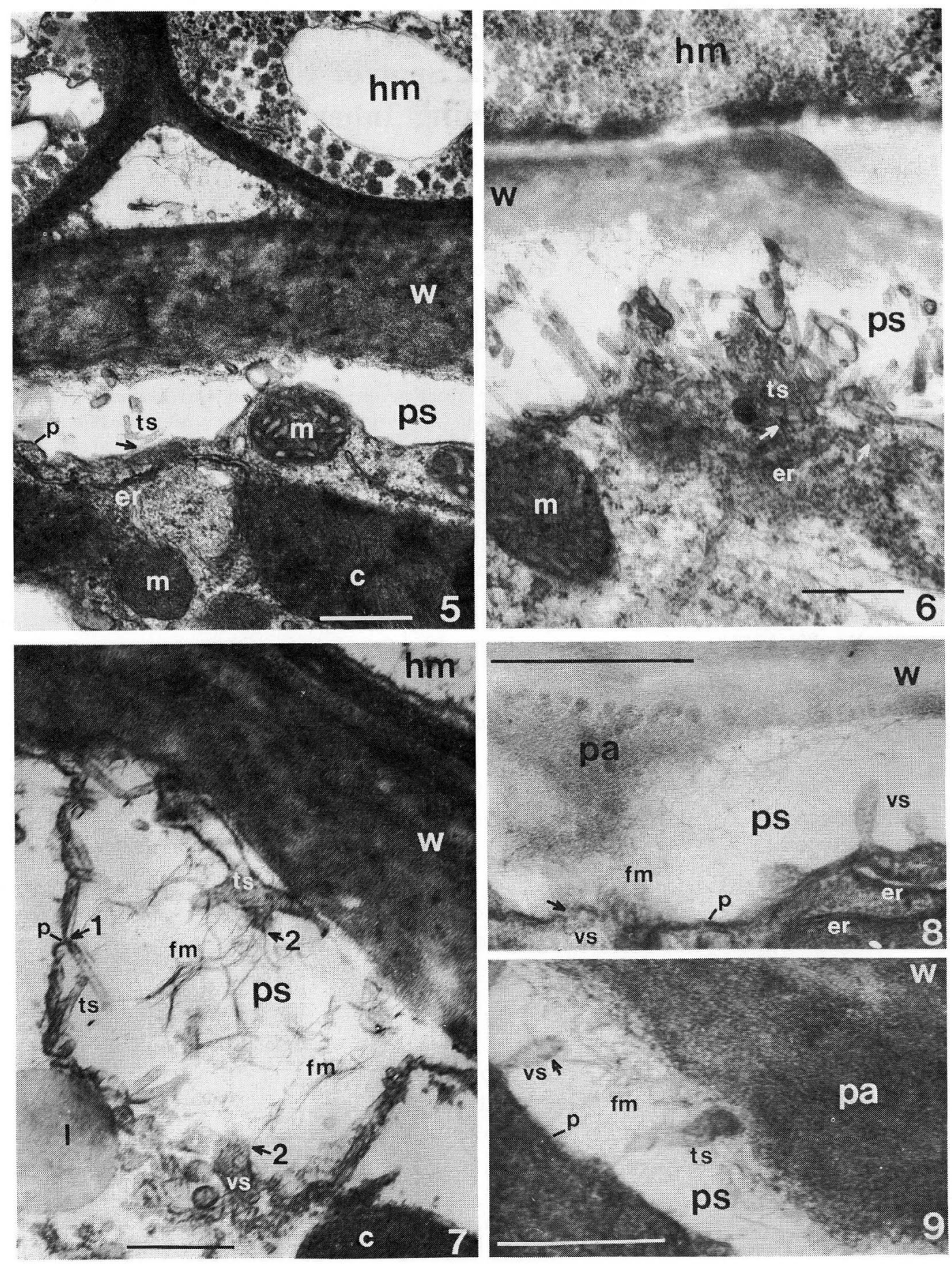